\title{
IMPACT OF ISRA'ILIYYAT REPORTS ON THE ISLAMIC CREED OF CONTEMPORARY MUSLIMS
}

\author{
Attahir Shehu Mainiyo ${ }^{1}$ \\ Department of Islamic Studies, \\ Usmanu Danfodiyo University, Sokoto, Nigeria \\ shehu.mainiyo@udusok.edu.ng \\ +2348060060197; +2348095534198 \\ $\&$ \\ Muhammad Sani Abdullahi ${ }^{2}$ \\ Department of Islamic Studies, \\ Usmanu Danfodiyo University, Sokoto, Nigeria \\ saniabdallah@yahoo.com \\ +234 $8034370802 ;+2348092677772$ \\ URL: http://ijourels.org.ng $\quad \underline{\text { https://dx.doi.org/10.4314/ijrs.v7i1.5 }}$
}

\begin{abstract}
In Islamic literature sacred histories and particularly narratives of the Prophets and saintly people have suffered much distortion and manipulation by Qassasun ${ }^{3}$ or simply storytellers. The trend gave writers unprecedented chance of being storytellers, and it is from such works that they draw their tales ${ }^{4}$. The spread of Islam and its subsequent acceptance by Judaism and Christianity paved way for assimilation and exchange of ideas and tradition among the adherents of the three religions. This trend of sourcing information from other religions in order to understand Islam is considered by some scholars to be a potential threat and possible cause for confusion among the Muslims. It has however affected Islam in various ways. One of such ways is the pattern, method and the manner in which inauthentic reports known as Isra'iliyyat reports are brought into the Islamic traditions particularly by Qur'an commentators. ${ }^{5}$. Regrettably, the trend has seemingly affected the foundational principles of Islamic faith (Aqidah) such as the belief in Allah (S.W.T.), His Prophets, and previous (sacred) revelations such as Taurat (Torah), Zabur (Psalm) and Injil (Gospel). The paper, in line with this backdrop, attempts to answer the questions listed here and other relevant ones in order to unravel the impact of Isra'iliyyat reports on the Aqidah of contemporary Muslims. How do the Isra'iliyyat reports spread among the contemporary Muslims and how best it could be handled? How often did Isra'iliyyat reports treat certain aspects dealing with Islamic Aqidah? To what extent does the use of Isra'iliyyat reports affect Islam and harms the Muslim faith? How to identify Isra'iliyyat reports and assess their usage on the basis of sifting technique? Does the understanding of the Glorious Qur'an require any additional information sourced from Isra'iliyyat? Is the use of Isra'iliyyat necessary for Muslims? How rapid and accelerated was Isra'iliyyat reports since the time of the Sahaba (the Prophet's Companions) and their followers to the present time? Was it permitted to use Isra'iliyyat reports in areas that do not contradict the Shari'ah or downgrade one of the Prophets of Allah? To achieve the objectives of the research, we adopted analytical phenomenological methodology.
\end{abstract}

Keywords: Impact, Isra 'iliyyat, Aqidah Contemporary Muslims, Injil 


\section{Introduction:}

The presence of inauthentic narratives otherwise known as Isra'iliyyat reports has seemingly affected the Aqidah of contemporary Muslims. This is because; some of these Isra'iliyyat reports treated certain aspects that have to do directly with Islamic Aqidah ${ }^{6}$. Consequently, the much circulated inauthentic reports sneaked into voluminous works of some of the Qur'an exegetes. In order to curtail the growing effect of such inauthentic reports, some Muslim scholars have over the years devoted their precious time to writing individual works about the status and transmission of Isra' iliyyat reports ${ }^{7}$. This is perhaps done in order to unravel the danger and implication articulated in those reports. It is therefore the intent of this paper to highlight the impact of those inauthentic reports and possibly the extent of their usage among the contemporary Muslims.

\section{Concept Definition}

The term Isra'iliyyat derives literally from the Arabic word Isra'iliyyah. It is therefore the plural form of Isra'iliyyah. Isra'il is also known, in the lighter form of the word, Isral which means Allah's chosen servant or simply Allah's servant ${ }^{8}$. The Glorious Qur'an generally uses the term Banu Isra'il when it refers to the Jews; and it occurs fifty three (53) times in the Qur'an'.

Al-Baydawi is of the view that Ya'qub (A.S.) is referred to as Isra' il ${ }^{10}$ whose mention occurred in many verses of the Qur'an as can be seen in the following verses:

Those among the Children of Israel who disbelieved were cursed by the tongue of Dawûd (David) and 'Iesa (Jesus), son of Maryam (Mary). That was because they disobeyed (Allâh and the Messengers) and were ever transgressing beyond bounds. (Q 5:78)

And We decreed for the Children of Israel in the Scripture, that indeed you would do mischief on the earth twice and you will become tyrants and extremely arrogant! (Q 17:4)

Verily, this Qur'ân narrates to the Children of Israel most of that about which they differ. (Q 27:76)

His twelve children were Israelites. Some Muslim scholars are of the view that every foreign element in exegesis is called Isra'iliyyat ${ }^{11}$. This might not have been unconnected with the modern approach to the study of Isra'iliyyat which made it to be taken as a subject of study in Islamic or an oriental study, as it was not, as a subject of study, discussed by the early scholars of Islam ${ }^{12}$. They instead, used the terms such as Al-Ahadith Al-Isra'iliyyah, Akhbar Banu Isra'il, Riwayat Al-Yahud, Akhbar Nasraniyyah, Riwayat Ahl-Alkitab and other related terms. Razali emphasizes that in the Hebrew language, the term is referred to as Yisra'el, which also denotes Ya'qub or Jacob in the context of Judaism ${ }^{13}$, hence the following explanations: 
Jacob, in the process of spiritual growth, has a physical struggle with God. Injured in this struggle, Jacob's name is changed to Yisrael, or Israel, translated 'the one who struggles with God.' The struggle itself becomes the spiritual marker by which the Jews identify themselves. The Torah most often refers to the Israelites as Banei Yisrael, the Children of Israel. They are the spiritual ancestors of the modern Jewish people. The Rabbis taught that the Israelites descended from the best that was within Jacob. Thus, the spiritual charge of the Israelites, and then of the Jewish people, was to be like Jacob/Israel - to struggle with God and, in the end, observe the moral and ethical mandates by their own choice. ${ }^{14}$

Razali however noted that the reason for this change of name from Jacob to Israel is due to his victory in his struggle with $\operatorname{God}^{15}$ as was mentioned in Genesis:

And he said, Thy name shall be called no more Jacob, but Israel: for as a prince hast thou power with God and with men, and hast prevailed ${ }^{16}$

In restrictive term, the word Isra'iliyyat, in the context of this presentation, denotes narratives from the Jewish source(s) and by extension, other sources from the Christians ${ }^{17}$. The word is therefore restricted to only source(s) from the people of the book or Ahl Al-Kitab. These sources include both news from the Jews (Isra'iliyyat) and the Christians (Nașraniyyat) and that a number of these citations emanated from the Tawrah, Zabur as well as the Injil $^{18}$. This is because the Qur'an and other revelations share some commonality with one another, particularly narratives of Prophets and Messengers mentioned in them. Such narratives have somehow negatively impacted on the religious lives of contemporary Muslims. Much of these narratives have treated certain aspects dealing with Islamic Aqidah ${ }^{19}$.

As a result of this trend, inauthentic reports sneaked into voluminous works of Qur'an exegetes. But however, Abu Shahbah is of the view that the usage of the term Banu Israel terminated in the time of the Prophet. Thus, what apparently appears is that the term can still be applied to all that came through the lineage of children of Prophet Ya'qub (A.S.) and by extension anyone who accepts Judaism as a religion. ${ }^{20}$ Largely, Isra'iliyyat cover information sourced from Al-Taurah, Zabur and Injil being the scriptures given to Prophets Musa, Dawud and Isa $(A S)$ respectively. Other groups of scholars have expanded the term to accommodate other non-Muslim narratives and other foreign elements in the Qur'anic exegesis ${ }^{21}$.

Some scholars, according to Albayrak consider the term a subdivision of Qisas Al-Anbiya or narratives of the Prophets. The specific usage of Isra'iliyyat on different elements is appropriate when material obtained from Jewish sources greatly predominates ${ }^{22}$. Jews are but people with strongest enmity to the believers and Islam as was elucidated in the Qur'an. Almighty Allah says: 
Verily, you will find the strongest among men in enmity to the believers (Muslims) the Jews and those who are Al-Mushrikûn (see V.2:105), and you will find the nearest in love to the believers (Muslims) those who say: "We are Christians." That is because amongst them are priests and monks, and they are not proud. (Q 5:82)

They are, being civilized, within a walking distance to Muslims and engaged in making all they could to smear the image of Islam.

Abd Allah bin Saba'i, who was one of the Jews seeks discord, in his manifest error, to spread doubt among the Muslims, particularly on issues that have creedal touch. It is generally believed that Aqidah forms the basis of Islamic religion whose objective is to produce Islamic Ummah who has Godconsciousness in all aspects of their lives. It is therefore very important to identify such reports which have no basis and strong sources and to employ a sifting technique through which the usage and the spread of Isra'iliyyat among the contemporary Muslims will be minimized or drastically reduced.

\section{Emergence and Usage of Isra'iliyyat Reports}

Israelites have, most frequently, appeared in Qur'anic commentaries as well as related works on the narratives of the Prophets. It followed as a result of some early Muslims who were converts from Judaism and Christianity and who brought with them much lore from their own source (s). Such traditions are consequently integrated into the earliest Qur'an commentaries and became a significant part of the Muslim exegetical traditions. One of the best known transmitters of Isra'iliyyat is Wahb b. Munabbih who wrote a book, though no longer extant, entitled 'Isra'iliyyat'. Muslim scholars had dispelled such traditions despite the fact that understanding many of the narratives in the Glorious Qur'an requires additional information supplied by the Qur'an itself, Hadith/Sunnah of the Prophet (S.A.W.) and most of the time Isra'iliyyat. Other Muslim exegetes, though they preserved such Isra'iliyyat in their works, opined that the reliability and credence of such narrations are questionable. The usage of Isra'iliyyat in the works of Tafsir is not something which happened without any possible reasons.

Using source(s) from other religions to understand Islam, expressly in this case of Isra 'iliyyat seems confusing. This issue is not only limited to the Muslims per se but also prompt questions from the Jews and the Christians as to why Muslims would go to the Torah and the Bible to understand Islam. This is borne out of the fact that there are implications in Biblical interpretation on the Islamic contexts which Muslim scholars should re-visit and discuss thoroughly. The religion of Islam, as Muslims believe encourages humankind to return to the message of Allah revealed to His Messengers for their guidance. While some Muslim scholars did restrict the usage of Isra'iliyyat to only source(s) from Ahl Al-Kitab or people of the book which include citations from Al-Taurah, Zabur and Injil, others upheld a different view. The term, they argue, refers to the 
traditions and reports that contain elements of the legendary and religious literature of the Jews. More often, Muslims embark on their way towards understanding Islam through the people of the Book. This includes but is not limited to theological, scriptural, ritual and spiritual teachings.

Resorting to Isra'iliyyat by the Companions of the Prophet could be regarded as the fourth source, after the Qur'an, Hadith/Sunnah and Ijtihad. However, Isra'iliyyat according to scholars of Qur'an can only be used as examples but not to be taken to strengthen any Qur'anic verse. ${ }^{23}$ The difference between the Qur'an, as the first source, and Isra'iliyyat in describing narratives of Prophets and the previous nations in a more pictorial manner is that the Qur'an applied a unique approach which does not explain things in details ${ }^{24}$. It does not also complete a narrative from its many aspects but only summarizes things for instructional purposes. Although the mind always longs for complete explanation on certain things and at length this desire therefore had caused many among the Companions of the Prophet to refer to many things for additional information, which are not thoroughly detailed in the Qur'an, to the Muslim converts such as Abd Allah Ibn Salam and Ka'b Al-Akhbar who were from among the scholars of Judaism and Christianity.

History has it that Muslim scholars were so inquisitive and curious on the actual interpretation and understanding of certain narratives of Prophets and previous nations, which are mentioned in a condensed form in the Qur'an. This made them to specifically seek for explanation and description of such narratives, the trend that opened many gates of Isra'iliyyat. Literary contributions of early Muslim scholars like Ibn Abbas, ${ }^{25}$ Muhammad Ibn Jarir Al-Tabari ${ }^{26}$ and Ibn Kathir $^{27}$ are clear testimony in this regard. The emergence of numerous Isra'iliyyat in the works of early Muslim scholars does not mean that they are acceptable in their entirety; this is because of the existing criteria of sifting any report(s) for its reliability before being accepted or otherwise. Objectively, Abu Hurairah (R.A.) was reported to have cleared the air that:

The People of the Book read the Torah in Hebrew and explained it in Arabic. On this matter the prophet (S.A.W.) said 'Do not confirm the People of the Book, and do not accuse them of falsehood,' but say that 'we believe in God and what He has revealed to us. ${ }^{28}$

Ibn Mas'ud (R.A.) had similar reports as a command from the Prophet who expatiates that:

Do not ask the People of the Book themselves because they will not guide you having already led themselves astray. ${ }^{29}$

Jabir bn Abd Allah (R.A.) on a similar issue reported that:

'Umar (RA) the second Caliph wrote some parts of Al- Taurah in Arabic and brought it to the Prophet (S.A.W.). When he started reading what he wrote, the face of the Prophet changed. Then one of the people of Madinah told 'Umar: 'Shame on you O 'Umar! Look at the face of the Messenger of Allah.' The Prophet said 'Do not ask the People of the 
Book about anything, for they will not show you the right path, having already led themselves astray. Otherwise you accuse the truth of falsehood and confirm the wrong; I swear that even if Prophet Musa (AS) was alive among you nothing would be opened to him but to follow me. ${ }^{30}$

Generally, the trend of sourcing information from other religions in order to understand Islam is considered to be a potential threat and possible cause for confusion among the Muslims. It also shows an extremely strict attitude towards any knowledge being derived from the People of the Book. Muslims are explicitly discouraged from referring to such dubious narrations. Many Muslim scholars as a result, upheld the view that the use of Isra'iliyyat is no longer necessary. It has clearly accentuated an attitude of rejecting the Isra'iliyyat and other non-Muslim information from being accessible by Muslims. ${ }^{31}$

Na'na'ah, in his submission strongly emphasizes that the use of Isra'iliyyat affects Islam and harms the Muslim faith ${ }^{32}$. This opinion has also been expressed by Alkhalidi ${ }^{33}$ who stresses that the use of Isra'iliyyat can only confuse the Muslims because of inadequate accuracy of such narratives retrieved from the people of the Book. In this situation Isra'iliyyat cannot be used to interpret the Glorious Qur'an. In spite of these negative clauses on the use of Isra'iliyyat still some group of Muslim scholars see no harm in the utilization of such material in their different works. Conversely, the opinion has contradicted the Qur'anic verse(s) in which Almighty Allah mentioned that the people of the book altered their own books, corrupted and distorted their scriptures. Almighty Allah explains:

Then woe to those who write the Book with their own hands and then say, 'This is from Allah,' to purchase with it a little price! Woe to them for what their hands have written and woe to them for what they earn thereby (Q 2:79).

What is broadly implied here is that all knowledge of religious matters necessary for Muslims to be guided is obtainable from the Glorious Qur'an. ${ }^{34}$

\section{Storytellers and the Spread of Isra'iliyyat Reports}

Storytelling is an ancient vocation and there used to be an intimate relation between the storytellers and their audience. Both the storytellers and the listeners are physically close, often seated together mostly in a mosque and in a circular fashion. Through the telling of the story people become spiritually close, developing a connection to one another through communal experience. The storyteller reveals and shares his knowledge with listeners.

The intimacy and connection therefore is deepened by the flexibility of the storytelling and that creates a personal bond between the teller and the audience. It is through this harmonious relationship that storytellers find it easy to disseminate unauthentic reports which were carried on by significant number of their listeners. 
Moreover, the spread of Isra'iliyyat continued to witness rapid and accelerated boost since the time of the Sahaba (R.A.) though, they have not made use of them except those that have not contradicted the Shari'ah or portrayed and downgraded one of the Prophets of Allah. This development continued until the year 224 AH when Ibn Jarir Al- Tabari wrote his work on Tafsir entitled 'Jami' Al-Bayan fi Tafsir Al-Qur'an'. In this Tafsir, Al-Tabari tried to distance his work from narrating any unauthentic report related to Prophets and Messengers of Allah. If he must to do that, he made sure they were accurately transmitted from Ahl Al-Kitab who had accepted Islam before; like Ka'ab Al-Akhbar, Wahb Ibn Munabbah, Abd Allah bn Salam and Ibn Juraij to mention a few. ${ }^{35}$

Al- Tabari's methodology is borne out of the fact that various works on Tafsir do contain Isra'iliyyat that are mendacious in contents and contexts and cannot therefore be verified. Most of the authors made those Isra'iliyyat available in their works without substantiating their veracity. The iterated Isra'iliyyat on this regard therefore is that of angels Harut and Marut mentioned in chapter two of the Qur'an. Almighty Allah, in different verses of the Glorious Qur'an confirmed the angels and made them infallible, signifying that they were incapable of being erroneous in anything they do.

Despite Isra'iliyyat being widespread, studies have shown that there are quite a number of Tafsir works that are, to some extent, rid of Isra'iliyyat as a result of extra care taken before accepting any Isra'iliyyat to be documented in their works. These works include but are not limited to the following:

1. Jami' Al-Bayan fi Tafsir Al-Qur'an authored by Ibn Jarir Al-Tabari

2. Bahrul Ulum by Abu Laisi Al-Sarmakandi

3. Al-Kashfu wa Al-Bayan an Tafsir Al-Qur'an by Abu Ishaq AlTha'alabi

4. Ma'alim Al-Tanzil by Al-Hussaini Al-Baghawi

5. Al-Muharrar Al-Wajiz fi Tafsir Kitab Al-Aziz by Ibn Atiyyah

6. Tafsir Al-Qur'an Al-Azim by Abul Fida' Al-Hafiz Ibn Kathir

7. Al-Jawahir Al-Ihsan fi Tafsir Al-Qur'an by Abdulrahman AsSa'alabi

8. Addurr Al-Mansur fi Al-Tafsir Al-Ma'sur by Jalaluddin Al-Suyuti

9. Tafsir Al-Mannan by Imam Al-Razi

Alternately, there are Qur'anic narratives where such Isra'iliyyat are more articulated than others. This includes the following:

1. Narrative of Harut and Marut found in chapter two of the

Qur'an

2. Narrative of Prophets Khidr and Musa (A.S.)

3. Narrative of $Y a^{\prime}{ }^{\prime} u j$ and Majuj

4. Narrative of Prophet Adam (A.S.) and Hauwa'

5. $\quad$ Narrative of Dhul-Qarnain

6. Narrative of Prophets Sulaiman and Dawud (A.S.)

7. Narrative of the flood 
8. Narrative of Prophet Musa (A.S.) and Pharaoh among others

\section{Some of the Isra'iliyyat in Books of Tafsir}

a. Narrative of Harut and Marut in chapter two of the Qur'an: When angels precisely noted the mischievous acts such as manslaughter, consumption of alcohol, adultery and fornication, etc perpetrated by the humankind they became worried and asked Almighty Allah, "O Allah! Are these Your chosen vicegerents on earth though they commit atrocities and mischievous acts?" Almighty Allah answered them saying: "Had you been created the same way as they were and subject you to lust as I did to them you will definitely err." They said how possible is that God? Upon this, He requested them to nominate two angels among themselves who will come down on earth as a test; and they chose the names of angels Harut and Marut. These angels were to stay with human folk and judge between them while on earth. Before they were taken to earth they were told not to commit shirk (associating partner with Allah), unlawful killing, consumption of alcohol and fornication. This continued day after another until when beautiful a woman named Zahra' approached them with a complaint about her husband. They were seduced by her love and had wanted to incline towards their desire (to fornicate with her). Instead of her to decline, she accepted with conditions that they must commit unlawful killing, fornicate, consume alcohol and prostrate before an idol. In addition to all that, she requested them to reveal to her what they normally recite when they go to heaven and earth. Instantly, they told her the greatest name of Allah! She recited it and was then taken up and was said to be turned to a star in the sky. Upon that Almighty Allah gave them an option to either be punished on the day of judgement or while they are on earth and they accepted the torment of this perishable world. As a result of their choice they are chained in the city of Babila in Iraq and afflicted with horrible torment.

This narrative and other similar ones mentioned in this pattern contradicted many Qur'anic verses and Ahadith of the Prophet that testify to the glory and veneration of the Angels who never and will never commit a sin.

2. $\quad$ Narrative of Iwaj the son of Anaku the daughter of Prophet Adam (A.S.): it has been established beyond doubt and the Qur'an confirmed that at the time of the Flood, Almighty Allah delivered His Prophet Nuh (A.S.) and all those who believed in him and were in the Ark. Despite Qur'anic verses and Ahadith confirming this, in one of the Isra'iliyyat it was reported that there was a certain man called Iwaj who was lanky and was not in the Ark. As a result of his leggy nature he used to catch a fish and stretched it over to the sun and has it fried. This narrative, and other related ones not cited here, disagree with the Qur'anic verses and cannot therefore be accepted as their authenticity is subject to verification. This is for the following reasons:

a. Almighty Allah told us that:

They denied him, but We delivered him and those with him in the ship, and We made them generations replacing one after another, while We drowned those who belied Our Ayats (proofs, evidences, lessons, signs, 
revelations, etc.), then see what was the end of those who were warned (Q 10:73).

Almighty Allah revealed to us that anything that is not carried along in the ship was drowned.

b. Every unbeliever was therefore destroyed by Allah

c. That man who is called Iwaj was a non-believer and was not in the ship, so he was destroyed.

3. Narrative of Prophet Sulaiman (A.S.): It was reported that Prophet Sulaiman's power and prowess to rule over the angels, men and animals over the world is tied to his ring. One day when he was with his wife, Aminatu removed the ring off his finger and went to answer the call of nature. Suddenly, one of the Jinns identified to be Sakhar came to Aminatu in the form of Prophet Sulaiman (A.S.) and took away the ring. He therefore sat on the throne and bestowed himself with the sovereignty and authority of Prophet Sulaiman (A.S.) and ruled over mankind and birds. When Prophet Sulaiman (A.S.) returned he asked his wife the whereabouts of the ring and told him that he had since collected it. Immediately, he went to the wasteland in search of the ring. There and then, after forty (40) days, the Jinn threw the ring into the ocean only to be swallowed by a fish that was sold later to Prophet Sulaiman (A.S.) who then regained it. This narrative has been labelled faulty and defective and thus rejected by most Qur'an exegetes.

\section{Classification (s) of Isra'iliyyat Reports}

Reports that were sourced from Isra'iliyyat are broadly classified into categories. The following categorizations are discussed below:

a. Authentic Isra 'iliyyat in its chain (Isnad) and the text (Matn)

b. Contents that deal with the creed, Aqidah: It deals with issues surrounding the Aqidah. This is best understood in the following Hadith reported by Imam Bukhari.

Narrated 'Abdullah (R.A. $)^{36}$ :

A (Jewish) Rabbi came to Allah's Apostle and he said, "O Muhammad! We learn that Allah will put all the heavens on one finger, and the earths on one finger, and the trees on one finger, and the water and the dust on one finger, and all the other created beings on one finger. Then He will say, 'I am the King.' Thereupon the Prophet smiled so that his pre-molar teeth became visible, and that was a confirmation of the Rabbi. Then Allah's Apostle recited: 'No just estimate have they made of Allah such as due to Him' (Q 39:67).

c. Contents that deal with Islamic injunctions: Imam Bukhari narrated, in the Book of Tafsir under verse ninety-three (93) of Ali Imran that Abd Allah bn 'Umar (R.A.) reported that: 
The Jews brought to the Prophet a man and a woman from among them who had committed illegal sexual intercourse. The Prophet said to them, 'How do you usually punish the one amongst you who has committed illegal sexual intercourse?' They replied, 'We blacken their faces with coal and beat them,' He said, 'Don't you find the order of Ar-Rajm (i.e. stoning to death) in the Torah?' They replied, 'We do not find anything in it.' 'Abdullah bin Salam (after hearing this conversation) said to them. 'You have told a lie! Bring here the Torah and recite it if you are truthful.' (So the Jews brought the Torah). And the religious teacher who was teaching it to them, put his hand over the Verse of Ar-Rajm and started reading what was written above and below the place hidden with his hand, but he did not read the verse of Ar-Rajm. 'Abdullah bin Salam removed his (i.e. the teacher's) hand from the verse of Ar-Rajm and said, 'What is this?' So when the Jews saw that verse, they said, 'This is the verse of Ar-Rajm.' So the Prophet ordered the two adulterers to be stoned to death... ${ }^{37}$

d. What is in conformity and agrees with the Divine Law (Shari'ah): An example here is what Imams Bukhari and Muslim reported in their collections, as follows:

The Prophet said, 'The (planet of) earth will be a bread on the Day of Resurrection, and The resistible (Allah) will topple turn it with His Hand like anyone of you topple turns a bread with his hands while (preparing the bread) for a journey, and that bread will be the entertainment for the people of Paradise.' A man from the Jews came (to the Prophet) and said, 'May the Beneficent (Allah) bless you, O Abul Qasim! Shall I tell you of the entertainment of the people of Paradise on the Day of Resurrection?' The Prophet said, 'Yes.' The Jew said, 'The earth will be a bread,' as the Prophet had said. Thereupon the Prophet looked at us and smiled till his premolar tooth became visible.... 38

e. What is not in conformity and disagrees with the Divine Law (Shari'ah): This include numerous reports concerning Prophet Harun (A.S.) who was accused, in such Isra'iliyyat reports, of making a calf and then calling for its worship. Among this also is the report that Almighty Allah, after creating earth and heavens within six (6) days, rested on the seventh $\left(7^{\text {th }}\right)$ day. In addition to this however, is the most iterated report against the personage of Prophet Sulaiman (A.S.). It went to such an extent that Satan slept with Prophet Sulaiman's wives while in menstruation.

f. What the Shari'ah becomes silent on it and could not be found in the Divine texts: In such kind of report there could be neither proof to back it nor does it have any evidence to reject it at all. Imam Ibn Kathir, to buttress this point, reported in his Tafsir the episode of a certain man among the Israelite who was a wealthy man and was bestowed with a daughter. His brother's son developed interest in her 
and asked her hand in marriage, but his offer was turned down by her father. The son became infuriated and said 'by God I will kill him, take his wealth, marry his daughter and claim his blood money'. That man lulled him and moved out with him in the night and killed him. In the morning, he disguised looking for revenge as if he had no information on this nefarious act. When the matter was brought before Prophet Musa (A.S.) they demanded that should he invoke Allah to make clear to them who is the culprit... until when Allah revealed verses 67-74 of chapter two of the Glorious Qur'an on the slaughtering of the cow in Surah Al-Baqara.

Going by the above categorizations it is assumed that the Isra'iliyyat is divided into three. The first is acceptable, the second rejected and the third is tacit (i.e. understood without being openly expressed).

\section{Impact of Isra'iliyyat Reports on the Aqidah of Contemporary Muslims}

Isra'iliyyat reports, as discussed in the preceding pages, are reports from the Jewish and Christian's source (s). Such reports cannot be easily trusted as their accuracy and reliability are flawed. Scholars, students and researchers should be alive to their responsibility in making sure that such inauthentic reports are identified, itemized and their uses banned. This is because the usage of such reports is crucial in weakening the already established sound Aqidah of contemporary Muslims. The extent to which Isra'iliyyat reports have seemingly influenced and damaged the Aqidah of Muslims is very vital as most of these unverified reports discuss foundational principles of Islam such as belief in Allah, His Prophets, Paradise and Hell as well as moral principles. Many Muslim exegetes provide such faulty narratives in a number of pages in their different works of Tafsir in the course of interpreting Qur'anic passages. ${ }^{39}$

This perhaps, uncovers various traditions regarding Isra'iliyyat reports; though some other Muslim scholars have expressed consternation over the widespread as well as the impact that resulted from the usage of Isra'iliyyat on the Aqidah of contemporary Muslims. Many Qur'an commentators had made, in several passages of their Tafsir books, references to such Isra'iliyyat; one of such works include 'Tafsir Al-Jalalain, co-authored by Jalaluddin Muhammad bn Ahmad Al-Muhalli and Jalaluddin Abdulrahman bn Abi Bakr Al-Suyuti. ${ }^{40}$

In spite of the efforts of some contemporary Muslim scholars such as Shaykh Abd Allah of Gwandu, one of the Jihad leaders of Sokoto Caliphate, in sifting and scrutinizing Isra'iliyyat in the books of Tafsir, other scholars have continued to iterate such inauthentic reports in their Tafsir books or at various places where they conduct Tafsir particularly during the month of Ramadan. Shaykh Abd Allah as an erudite scholar, made a gigantic effort in identifying Isra'iliyyat with a view to making sure that his popular book of Tafsir entitled 'Diya' Al-Ta'wil fi Ma'an Al-Tanzil, is free of such faulty narratives. 
Despite the effort of the Shaykh, some other Muslim scholars have detected a insignificant number of Isra'iliyyat in his book. This is part of the human imperfection! One should note that in spite of Shaykh's prowess, in-depth knowledge and skills, he never claimed perfection. ${ }^{41}$ Some other contemporary Muslim scholars played significant roles in disseminating the Isra'iliyyat specifically during the month of Ramadan not knowing the implication of doing so or they did it out of passion. Some of the scholars who conduct Tafsir during the month of Ramadan relied solely on Isra'iliyyat to buttress their points of argument which sometimes centered on the narratives of Prophets Dawud, Sulaiman and Musa (A.S.), as well as angels Harut, Marut and Pharaoh, respectively. ${ }^{42}$ These mendacious reports affect, most of the times, Muslim's creed. Those who listen to such scholars consider Isra'iliyyat with utmost veneration and this has negative implication on their faith. ${ }^{43}$ Such 'unqualified or quack scholars' who conduct Tafsir in the month of Ramadan and other special occasions can negatively affect one's faith.

Summarily, the effect of such narratives on the Aqidah of contemporary Muslims can broadly be seen in the following points:

1. Uncertainty in almost all the narrations that are found in the books of Tafsir. This could mean that the spread of such narrations among the contemporary Muslims has its devastating effect which almost left the Muslims wandering with no conviction in accepting any report that relates to the Prophets of Allah, saintly people as well as important events that happened in the history of Islam.

2. The defect and deformity that are occasionally attributed to the Prophets of Allah in many of such narrations are worrisome. Such defective narrations are apparently noticed, for instance in the narratives of Prophets Sulaiman and Shu'aib (A.S.) as elucidated previously. To safeguard their faith, Muslims should therefore distance themselves from such mendacious reports.

3. Lack of accuracy, truthfulness and reliability of those reports in the books of Tafsir has made the Muslims disregard the authentic ones among the iterated ones. This has inadvertently taken some of the contemporary Muslims to such an extent of mixing the adulterated reports with the authentic ones; making it difficult for them to separate them accordingly. This development has resulted from the oversight of some of the Mufassirun to get rid of reporting such reports that are generally sourced from the Jews and Christians.

In order to suitably proffer the resolution to such tarnishing reports on the personages of the Prophets of Allah and other notables among the pious men, contemporary Muslims should stick to books of Tafsir written by eminent scholars whose integrity and sincerity are not doubtful and whose works on 
Tafsir are, to some extent reliable and accurate. They should also avail themselves with the knowledge of sifting technique through which they can distinguish between misleading and trustworthy reports. The latter refers to those reports that are acceptable, and do not attribute any defect, in whatever form, to the Prophets and Messengers of Allah and which do not go contrary to the Divine texts, while the former are those reports that go otherwise.

Comparatively, nothing brings out the contrast between Islam and Christianity as much as a comparison between Muslim and Christian attitudes towards Prophet Isa (A.S. $)^{44}$. He was never to be God but instead a chosen and Godly man and as the Messiah of the Jews to revive the true religion and bring to completion the long line of Israelite Prophets. ${ }^{45}$

\section{Conclusion}

Islamic faith is acquired by virtue of learning, constructive conceptions, and positive actions. Hence the Qur'an and the Sunnah of Prophet Muhammad (S.A.W.) define these required measures and establish the standards which build up meaningful faith. Muslims are therefore expected to take all necessary steps to ensure that their faith remains as concrete as possible in order not to lose it at the hands of quack 'scholars' who interpret Qur'anic verses mendaciously. This further necessitates urgent call to change this ugly trend which may take any negative dimensions in the Muslim world. Muslims' faith would thus make Islam penetrate deeply and constructively into every aspect of their lives, meaning that one's faith must have a decisive effect on one's spiritual, moral and social actions. 'Umar bn Al-Khattab (RA), the second Caliph, having understood the danger encircled in the transmission of Isra'iliyyat cautioned Ka'ab Al-Akhbar to be careful.

The study also discovered that in addition to 'Umar bn Al-Khattab's warning, there were a number of individual works on the status and transmission of Isra'iliyyat reports in order to uncover the danger rooted in those reports. Despite the presence of these works, some Muslim scholars however had conclusive explanation that after Islam had been established, the transmission of those reports could no longer do any harm; as a result of which many Isra'iliyyat reports find their way into classical exegesis. 


\section{Notes and References}

1 Mainiyo is a Lecturer I in the Department of Islamic Studies, Faculty of Arts and Islamic Studies, Usmanu Danfodiyo University, Sokoto

2 Abdullahi is an Assistant Lecturer in the Department of Islamic Studies, Faculty of Arts and Islamic Studies, Usmanu Danfodiyo University, Sokoto

3 As an Arabic word, it refers to storytellers as commonly used in Islamic tradition.

4 G. K. Merguerian and A. Najmabadi, "Zulaykha and Yusuf: Whose Best Story?", International Journal of Middle East Studies, Vol. 29, No. 4, (1997), 494.

5 Mal. Yahaya Muhammad Boyi, an Islamic scholar, 56 years, interviewed at his residence at Gidan Uban-Doma, Sokoto on 09th/08/2016. Other Arabic sources valuable for this research were equally obtained from this scholar.

6 M.H. Adh-Dhahabi, "Al-Isra'iliyyat fi Al-Tafsir wa Al-Hadith”, Maktabat Wahbah, Alqahirah, (nd), 14.

7 One of such works identified by Sakhawi is Al-Asl Al-Asil fi Tahrim Al-Naql min Al-Taurat wa Al-Injil. For details see Kashf Al-Zunun,by Khalifa,

8 Muhammad Murtaḍā al-Zabidi,. Taj Al-'Arus Min Jawahir Al-Qamus, (Taḥqiq: 'Abd Al-Sattar Aḥmad Farraj), Kuwayt, Maṭba'ah Al-Ḥukumah, vol. 10, 1965, 52 .

9 Muhammad Fu'ad Abdul Baqi, Al-Mu'jam Al-Mufahras li AlFaz al-Qur'an Al-Karim, (Istanbul, 1987), 33

10 M.H. Adh-Dhahabi, "Al-Isra'iliyyat fi Al-Tafsir wa Al-Hadith”, (Al-Qairah, Maktabat Wahbah, nd), 13.

11 Gordon Newby, "Tafsir Isra'iliyyat", Journal of the American Academy of Religion, Thematic Issue S 47/4 (1979), 29.

12 Ramzi Nacnacah, Al-Isra'īliyyat Wa Atharuha Fì Kutub al-Tafsir, (Damascus: Dar al-Qalam, 1970), 72-73.

13 Rosen Goldenberg, The Origins of Judaism: From Canaan to the Rise of Islam, (Cambridge: Cambridge University Press, 2007), 2-3.

14 Sara Karesh and Mitchell M Hurvitz, "Israel," Encyclopaedia of Judaism, (New York: Facts on File, 2006), 321.

15 King James Bible, Genesis, chapter 32: verse 24-29

16 King James Bible, Genesis, chapter 32: verse 28

17 M.H. Adh-Dhahabi, "Al-Isra'iliyyat fi Al-Tafsir wa Al-Hadith”, (Al-Qairah, Maktabat Wahbah, nd), 13.

18 Wan Razali et el, 'Making Sense of the Use of Isra'iliyyat in Muslim Scholars', un-published article, (2016), 6.

19 M.H. Adh-Dhahabi, "Al-Isra'iliyyat fi Al-Tafsir wa Al-Hadith”, (Al-Qairah, Maktabat Wahbah, nd), 14

20 Muḥammad Muḥammad Abu Shahbah, "Al-Isra'īliyyat Wa al-Mawducāt Fī Kutub al-Tafsir” (Maktabah al-Sunnah,1408 AH), 12. 
21 Wan Razali et el, 'Making Sense of the Use of Isra'iliyyat in Muslim Scholars', un-published article, (2016), 6.

22 Isma'il Albayrak, "Qur'anic Narrative and Isra'iliyyat in Western Scholarship and in Classical Exegesis", Unpublished PhD Thesis submitted to the Department of Theology and Religious Studies, University of Leeds, (2000), 126.

23 Ibn Taimiyyah, Muqaddimah Fi Ușul al-Tafsir, (Beirut, Dar Ibn Hazm, 1994), 90.

24 Wan Razali et el, 'Making Sense of the Use of Isra'iliyyat in Muslim Scholars', un-published article, (2016), 8-9.

25 Ibn 'Abbas and Muhammad ibn Ya'qub Al-Fairuz Abadi, Tanwir Al-Miqbas min Tafsir Ibn 'Abbas, (Amman Institute for Islamic Thought, np, 2007).

26 Muḥammad ibn Jarir Al-Ṭabari, Tafsir Al-Tabari Jamic Al-Bayan An Ta'wil Ayy al-Qur'an, Hijr Li al-Tibacah Wa Al-Nashr Wa al-Tawzic Wa al-i'lan, (np), 2003.

27 Ibn Kathir, Tafsir al-Quran Al-cAzim. (Cairo: Muassasah Qurțubah, np), 2000.

28 Abu 'Abd Allah Muhammad b. Isma'il Bukhari, Sahih Al-Bukhari, (Beirut, Dar Ihya Al-Turath Al-Arabi nd), (Bab 25, Hadith no: 7362)

29 Dhahabi, Al-Isra' iliyyat fi Al-Tafsir Wa Al-Hadith, (Cairo, 1971), 70-71.

30 Ahmad bn Hanbal, Musnad, (Istanbul, 1992), Vol 3, Hadith no: 338 and 387

31 William Montgomery Watt, Early Islam, (Edinburgh University Press, 1991), $77-85$.

32 Ramzi Na'na'ah, Al-Isra'iliyyat wa Atharuha Fi Kutub Al-Tafsir, (Damascus, Dar Al-Qalam, 1970), 72-73.

33 Șalah 'Abd Al-Fattah Al-Khalidi, Ta'rif Al-Darisin bi Manahij AlMufassirin, (Damascus, Dar Al-Qalam, 2008), 219.

34 William Montgomery Watt, The Muslim Attitude to the Bible', Glasgow University Oriental Society, 16 (1955-56) as quoted in Isma'il Albayrak, 117.

35 Dhahabi, Al-Isra' iliyyat fi Al-Tafsir Wa Al-Hadith,( Cairo, 1971), 55-60.

36 Bukhari Book 6, Volume 60, Hadith No, 335 e-copy

37 Bukhari, Book 6, Volume 60, Hadith No, 79

38 Bukhari, Book 8, Volume 76, Hadith No, 527

39 Muhammad Bello (Goni) Muhammad Boyi, aged 45, Islamic teacher, interviewed at Ma'had Al-Tahfidh Al-Qur'an, Hubbaren Shehu Danfodiyo, Sokoto on 23rd June, 2016

40 Muhammad Bello (Goni) Muhammad Boyi, aged 45, Islamic teacher, interviewed at Ma'had Al-Tahfidh Al-Qur'an, Hubbaren Shehu Danfodiyo, Sokoto on 23rd June, 2016 
41 Muhammad Bello (Goni) Muhammad Boyi, aged 45, Islamic teacher, interviewed at Ma'had Al-Tahfidh Al-Qur'an, Hubbaren Shehu Danfodiyo, Sokoto on 23rd June, 2016

42 Malam Bashir Danfili, during 2016 Ramadan Tafsir discussed the narrative of Prophet Sulaiman (A.S.). In his elucidation he emphasized on the lost ring of Prophet Sulaiman and how the Jinn took it away from Prophet Sulaiman's wife. This narrative and other similar ones are detrimental to the personage of Prophet Sulaiman (A.S.) and any other Prophet. Scholars should always verify these types of reports before revealing them to public.

43 One of the effects of Isra'iliyyat on the creed of contemporary Muslims is noted during the month of Ramadan 1437AH/2016. A scholar while interpreting Qur' anic verses relating to Prophet Isa (A.S.) emphasized, out of ignorance, that he has possessed Nasut and Lahut. As far as Islam is concerned, whoever believes in the Godship of Prophet Isa (A.S.) or attributes qualities of Almighty Allah to him has indeed nullified his/her faith.

44 H.Y. Mabera, Revelation of the Truth: A Collection of Comparative Religious Book Series,(Kaduna, Sarumedia Publishers), 11.

45 U.A, Samad, A Comparative Study of Christianity and Islam, (New Delhi, Adam Publishers and Distributors, 2007), 28-29. 